\title{
Quality parameters of pink pepper seeds as sustainability indicators
}

\author{
Parámetros de calidad de las semillas de pimienta-rosa como indicadores \\ de sostenibilidad.
}

Aline Nahanna Carneiro Rodrigues¹; Gilmara Pires de Moura Palermo²; Madelon Rodrigues Sá Braz³; Tiago Böer Breier

\begin{abstract}
ARTICLE DATA
1 Researcher, Engenheira Florestal, Universidade Federal Rural do Rio de Janeiro. Rio de Janeiro, Brasil, aline. rodrigues@rjo.incra.gov.br

2 Professor, Dr. Universidade Federal Rural do Rio de Janeiro, Rio de Janeiro, Brasil, gilpalermo@hotmail.com

3 Professor, Dr. Universidade Federal Rural do Rio de Janeiro, Rio de Janeiro, Brasil, madelonsa@hotmail.com

4 Professor, Dr. Universidade Federal Rural do Rio de Janeiro, Rio de Janeiro, Brasil, tiagobreier@gmail.com
\end{abstract}

Cite: Rodrigues, A. N. C.; Palermo, G. P. M.; Braz, M. R. S.; Breier, T. B. (2020). Quality parameters of pink pepper seeds as sustainability indicators. Revista de Ciencias Agrícolas. 37(2): 27-39.

doi: https://doi.org/10.22267/rcia.203702.135

Received: September 302019 Accepted: December 172020

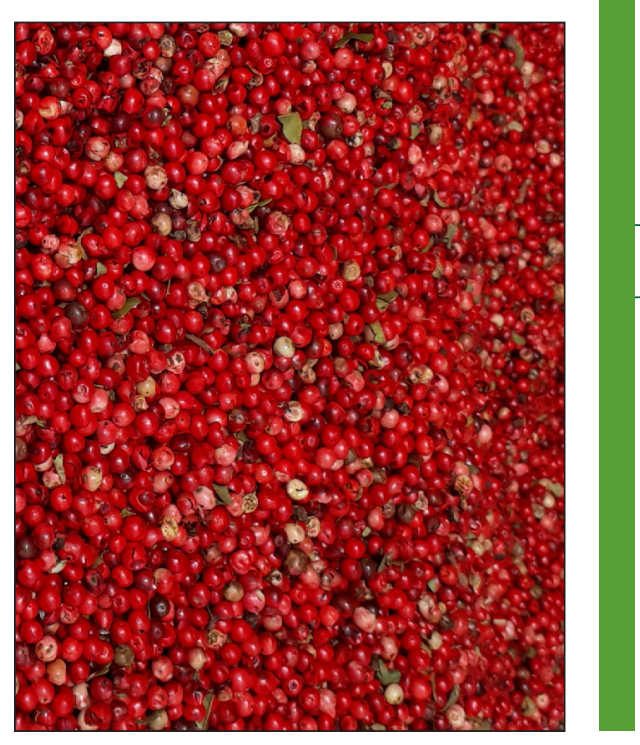

The poor management and marketing of rose pepper (Schinus terebinthifolius Raddi) in São Pedro D’Aldeia - RJ called the local governments' attention to adopt measures that favor the value chain, increase income, train rural producers, and launch the first Simplified Forest Management Plan. All of this, to authorize the sustainable management of this species. This study aimed to evaluate the quality parameters of pink pepper as sustainability indicators. The following was measured: the moisture content, purity, uniformity in the sieve, and the weight of one thousand seeds in samples obtained from three different batches. The germination test was only carried out for samples from lot 3. The results showed that the high moisture content of the seeds (22.99\%) has a negative effect on their quality, facilitating the action of spoilage organisms. The degree of purity was satisfactory (97.1\%). The seeds from lot 1 were larger and more uniform than the seeds from lots 2 and 3. Only lot 1 presented the weight of seeds compatible with that required by MAPA. The germination rate was $72 \%$, which did not vary between seeds of different sizes. The settlement's extractive activity is moving towards sustainability, which can be improved by incorporating good seed collection, processing and storage practices.

Keywords: S. terebinthifolius; seed analysis; rural settlement; sustainable development; extractivism.

\section{RESUMEN}

El inadecuado manejo y la comercialización de la pimienta-rosa (Schinus terebinthifolius Raddi) en São Pedro D’Aldeia - RJ, llamó la atención de los gobiernos locales sobre la adopción de medidas que favorezcan la organización de la cadena de valor; generación de ingreso; capacitación de productores rurales y la elaboración del primer Plan de Manejo Forestal Simplificado para autorizar el manejo sustentable de la especie. Este estudio tuvo como objetivo evaluar los parámetros de calidad de la pimienta-rosa como indicadores de sostenibilidad. Para ello se determinó: el contenido de humedad, pureza, 
uniformidad en tamiz y peso de mil semillas en muestras obtenidas de tres lotes diferentes. La prueba de germinación solo se realizó para muestras del lote 3. Los resultados mostraron que el alto contenido de humedad de las semillas $(22,99 \%)$ tiene un efecto negativo en su calidad, facilitando la acción de organismos deterioradores. El grado de pureza fue satisfactorio $(97,1 \%)$. Las semillas del lote 1 fueron más grandes y uniformes en comparación con las semillas de los lotes 2 y 3 . Solo el lote 1 presentó un peso de semillas compatibles con lo requerido por MAPA. La tasa de germinación fue del 72\%, la cual no varió entre semillas de diferentes tamaños. La actividad extractivita en el asentamiento avanza hacia la sostenibilidad, la cual se puede mejorar mediante la incorporación de buenas prácticas de recolección, procesamiento y almacenamiento de semillas.

Palabras clave: S. terebinthifolius; análisis de semillas; asentamiento rural; desarrollo sostenible; extractivismo.

\section{INTRODUCTION}

Pink pepper (Schinus terebinthifolius Raddi) is an Anacardiaceae native to Brazil. It is a helophyte plant that also grows in dry and poor soils. Its crown is rounded, and its trunk is tortuous with thick and cracked bark. It occurs from Pernambuco to Santa Catarina and Mato Grosso do Sul and, it is found in several vegetation formations, from the sandbank to the high semi-deciduous and rain forests (Neves et al., 2016).

The pepper exploitation in Rio de Janeiro began to intensify in late 1990's and has been growing in recent years with the main extractive activity in the region. The informal pink pepper market was evidenced around the 2000s due to the increase in the cargo seizures occurrences. In the state's scale of participation in exploring the species, Rio de Janeiro occupied first place, representing $42 \%$ of the market with 640 tons per harvest (Gomes et al., 2013).

Due to lack of legislation knowledge, management techniques for exploration and security, the collectors of Baixada Litorânea, especially those from the Ademar Moreira settelment farmers, acted without structuring the productive segment without knowledge about pruning techniques, fruit selection, processing, and storage.

Currently, the legal basis for the exploitation of pink pepper is provided by Federal Law n. 11.428/2006
(Presidência da República de Brasil, 2006) which requires an authorization instrument from the competent state or federal agency for the cutting, suppression, and commercial exploitation of trees in the Mata Atlântica biome, and the Resolution No. 124/2015 from INEA ch. V, art. 26 (INEA, 2015) which state the norms for Non-Timber Forest Products. If their exploration is carried out for commercial purposes, it will be considered Sustainable Forest Management and will depend on the presentation and approval of a Simplified Forest Management Plan for the forest species that will be exploited commercially.

In 2017, the SENAR-RJ (Serviço Nacional de Aprendizagem Rural-RJ) promoted the settlement farmers involved in extractives courses on pink pepper management and acceptable practices. Moreover, INEA contemplated the Settlement's Farmers Association with the first environmental authorization for species' sustainable forest management in May 2018, developed by the working team Aroeira (INEA, 2018). The three spheres of government acted together and actively elaborated the management plan, training and organizing of farmers and giving technical assistance.

The non-timber simplified forest management plan was first developed in the RJ state. It includes the exploitation of pink pepper inside the Ademar Moreira Settlement in collective legal reserve, 
regularizing this farmer's traditional activity. The authorization recognizes the Natural resources, sustainable economic exploitation importance for income generation in rural communities, and environmental conservation.

Inadequate harvesting and processing can result in a rapid deterioration and fruit quality loss, negatively affecting production sustainability. The lack of seeds quality can be expressed in the low uniformity index, degree of maturity, insects and fungi that hinder better yield in harvesting and marketing with a loss of market value for sale. The problem can be solved through better dissemination and technology transfer to harverst fruits appropriately and apply conservation or pre-processing techniques (Gomes et al., 2013).

In this way, the incentive for rural producers' technical qualificationconcerning acceptablepink pepper management practices is in accordance with two Sustainable Development Goals (SDG) established by United Nations (2015):

Goal n. 12: Ensure sustainable production and consumption patterns, aiming to contribute to 2030 agenda, achieving sustainable management and efficient use of natural resources and ensuring that people have relevant information for developing sustainable eco-friendly lifestyles; and

Goal n. 15: To protect, recover and promote the use of terrestrial ecosystems, managing forests, combating desertification, reserving land degradation and stopping biodiversity loss.

The low quality of the product directly interferes with market competitiveness and profit, making extractive activity unsustainable. Therefore, this work aims to analyze the quality of pink pepper seeds and guide producers to adopt appropriate techniques for collecting, conserving and, storing seeds; to increase the extractive activity's quality and sustainability.

\section{MATERIALS AND METHODS}

Characterization of the study area. Seed collection was carried out at the federal settlement Ademar Moreira (coordinates -22.713908, -42.108458), São Pedro D’Aldeia / RJ. The climate is tropical, with an average annual temperature ranging between 24 and $28^{\circ} \mathrm{C}$. November and December are the months with the highest rainfall, while June and July are the driest.

The settlement consists of 21 families. Sixteen are involved in the extraction of pink pepper, and part of the average family income comes from the sale of pink pepper.

The settlement comprises 487.68ha inserted in the Atlantic Forest biome. Of them, 180.37ha are intended to harvest pink pepper. However, each lot has an average of 20 individuals in management's potential (INEA, 2018).

Seed collection and analysis. The collection of seed samples from Lots 1 and 2 was carried out in loco. The samples were acquired from a bouquet of seeds from different pink pepper trees, harvested in May/2018 and June/2018. The sample from Lot 3, taken in May 2019, was acquired at a bioeconomy event (Green Rio), directly from Ademar Moreira settlement producers.

From each lot, samples composed of pink pepper seeds of adequate size for the tests and in similar proportions were obtained to guarantee uniform and accurate results in the analyses. The composed samples were taken at random and manually removed from the lots, each weighing approximately $1.000 \mathrm{~g}$.

The samples were stored in individual packages of transparent and impermeable plastic, identified; 
according to the lot they were collected. Subsequently, they were adequately packaged to avoid damage during transport, free of excess heat, humidity, and contamination. They were immediately sent to the Laboratory of Reproductive Biology and Conservation of Tree Species (LACON) in the Department of Silviculture/Forest Institute/ UFRRJ.

The procedures for analyzing the quality of pink pepper seeds were performed based on the "RAS - Rules for Seed Analysis" (MAPA, 2009 and MAPA, 2013), and the parameters determined were purity analysis; moisture content; uniformity in a sieve, the weight of a thousand seeds and germination and vigor test.

Purity analysis. Working samples of approximately $100 \mathrm{~g}$ were used; after weighing were placed on a smooth white surface. Then, the pure seeds. Other seeds and inert materials were separated manually and weighed individually on a scale with a precision of 0.0001 as described in the RAS (MAPA, 2009). The percentages were based on the sum of the component weights.

Determination of moisture content. The moisture content of the seeds was determined by the greenhouse method at $105 \pm 3^{\circ} \mathrm{C}$. Initially, from each lot, two $5 \mathrm{~g}$ subsamples were extracted from the $100 \mathrm{~g}$ working sample used in the purity test. The subsamples were initially placed in an aluminum crucible and weighed on a $0.001 \mathrm{~g}$ precision scale to determine the seeds' moisture content. Subsequently, they were sent to the greenhouse at $105 \pm 3^{\circ} \mathrm{C}$ and maintained for 24 hours. After the drying period, the subsamples were removed from the greenhouse, covered, and placed in a desiccator until cool. After being cold, they were weighed again, and the moisture content was determined based on the formula described in the RAS (MAPA, 2009).
Uniformity test (sieve retention). Two working samples of approximately $100 \mathrm{~g}$ of seeds from each lot were weighed, placed on a set of analysis sieves (tyler $3.5=5.6 \mathrm{~mm}$, tyler $4=4.75 \mathrm{~mm}$ and tyler $5.0=4.0 \mathrm{~mm}$ ), and the whole was shaken for one minute. The seeds retained in the sieves were separated, weighed and had their percentage calculated according to RAS (MAPA, 2009). Due to the ripe fruits of the pink pepper having an average of 4.0 to $5.5 \mathrm{~mm}$ in diameter, the seeds' percentages retained in the 5.66, 4.75 and $4.00 \mathrm{~mm}$ mesh sieves were considered.

Thousand seed weight. Eight repetitions of 100 seeds each, from each lot, were counted manually and at random. Then, the seeds of each repetition were placed in a petri dish and weighed. The result of the thousand seed weight test is the average weight of the repetitions of 100 seeds, multiplied by ten, according to RAS (MAPA, 2009).

Germination and vigor test. For the test, only the seed samples from Lot 3 (collected in May/2019) were used as they had shorter storage times. From this, 400 seeds retained in each sieve (Tyler 4 $4.75 \mathrm{~mm}$ and Tyler $5-4.0 \mathrm{~mm}$ ) were selected and divided into four repetitions of 100 . These seeds were soaked for 10 minutes in a neutral detergent solution at 5\% (5 drops of detergent per $100 \mathrm{ml}$ of distilled water); subsequently, the seeds were rinsed with distilled water and immersed in a $2 \%$ sodium hypochlorite solution for two minutes and washed again with distilled water. After asepsis, the seeds were distributed inside gearbox boxes, on two sheets of germintest paper previously sterilized in an autoclave. According to RAS, the paper was moistened with $4.5 \mathrm{~mL}$ of distilled water, an amount established based on the leaves' weight (paper weight $\times 3.0$ ). Then, the gearbox boxes with the seeds were placed in germination chambers (BOD) at a constant temperature of $25^{\circ} \mathrm{C}$ for 21 days. 
The germination test was evaluated three times, every 7 days until the $21^{\text {st }}$ day, by counting the formation of normal, abnormal seedlings, primary root emission, dormant and dead seeds as proposed by MAPA (2009) and MAPA (2013). Germinated seedlings were considered normal seedlings. The result of the germinated seedlings was expressed as a percentage $(\mathrm{G} \%)$, and the count of the number of seedlings germinated in the first seven days was used to analyze the vigor of the seeds.

Sustainability assessment. A scale of 1 to 3 was used to classify the seeds' quality parameters; based on scientific research results (bibliographic review) and normative instructions from
MAPA. Grade 3 is related to high sustainability, grade 2 to medium sustainability and grade 1 to low sustainability (Table 1).

Statistical analysis. The data obtained were analyzed using a statistical package STATISTICA 7.0. The experimental design used was completely randomized. The t-test was performed for the germination and vigor test to check if the differences between treatments are significant at the level of $5 \%$ significance (depending on the mesh); moreover, analysis of variance (ANOVA) and comparison between means by the Tukey test for the parameters moisture content, thousand seeds weight and uniformity in a sieve.

Table 1. Degree of sustainability based on seed quality parameters.

\begin{tabular}{|c|c|c|c|}
\hline \multicolumn{2}{|c|}{ Parameters } & \multirow{2}{*}{$\begin{array}{c}\begin{array}{c}\text { Sustainability } \\
\text { Degree }\end{array} \\
3\end{array}$} & \multirow{2}{*}{$\begin{array}{l}\text { Bibliographic references } \\
\text { for assigning grades }\end{array}$} \\
\hline \multirow{3}{*}{ Moisture Content } & $<12 \%$ & & \\
\hline & $12 \%$ a $20 \%$ & 2 & \multirow{2}{*}{$\begin{array}{l}\text { (Medeiros e Zanon, 1998) } \\
\text { e (Oliveira et al. 2018) }\end{array}$} \\
\hline & $>20 \%$ & 1 & \\
\hline \multirow{3}{*}{ Purity } & $>97 \%$ & 3 & \multirow{3}{*}{$\begin{array}{l}\text { Normative Instruction } \\
\text { MAPA } 45 \text { (2013) }\end{array}$} \\
\hline & $97 \%$ a $96 \%$ & 2 & \\
\hline & $<96 \%$ & 1 & \\
\hline \multirow{3}{*}{ Uniformity in Sieve } & High* & 3 & \multirow{3}{*}{$\begin{array}{l}\text { Carvalho and Nakagawa } \\
\text { (2000); Ponce et al. (2019) } \\
\text { e Rossi et al. (2017) }\end{array}$} \\
\hline & Medium** & 2 & \\
\hline & Low $^{* * *}$ & 1 & \\
\hline \multirow{3}{*}{$\begin{array}{c}\text { Thousand Seeds } \\
\text { Weight (seeds/Kg) }\end{array}$} & 37,000 a 44,000 & 3 & \multirow{3}{*}{$\begin{array}{l}\text { Normative Instruction } \\
\text { MAPA } 45 \text { (2013) }\end{array}$} \\
\hline & 44,001 a 45,599 & 2 & \\
\hline & $>46,000$ & 1 & \\
\hline \multirow{3}{*}{$\begin{array}{c}\text { Germination and } \\
\text { Vigor }\end{array}$} & $>80 \%$ & 3 & \multirow{3}{*}{$\begin{array}{l}\text { Normative Instruction } \\
\text { MAPA } 45 \text { (2013) }\end{array}$} \\
\hline & $80 \%$ a $60 \%$ & 2 & \\
\hline & $<60 \%$ & 1 & \\
\hline
\end{tabular}

${ }^{*}$ High uniformity refers to $100 \%$ of the seeds retained in the $5.66 \mathrm{~mm}$ and $4.75 \mathrm{~mm}$ mesh sieve. ${ }^{* *}$ Medium uniformity refers to more than $40 \%$ of the seeds retained in the $4.75 \mathrm{~mm}$ mesh sieve. ${ }^{* * *}$ Low uniformity refers to more than $40 \%$ of the seeds retained in the $4.0 \mathrm{~mm}$ sieve. 


\section{RESULTS AND DISCUSSION}

Purity analysis. According to the Normative Instruction 45 MAPA (2013), which establishes identity and quality standards for the production and commercialization of seeds, the analyzes for pink pepper seeds must present a satisfactory result of a minimum purity of $97 \%$. Thus, it can be seen that Lots 2 and 3 presented a high percentage of purity according to the determined standards. It is greater than $97 \%$, while Lot 1 presented $94.2 \%$ purity (Table 2 ).

The presence; and the number of impurities present in a seed lot are related to post-harvest procedures. The reduced amount of impurities in the samples corresponding to Lots 2 and 3 indicates that the producers performed a good manual cleaning (scavenging), adding value to the product and increasing the production sustainability.

Moisture content. The average values of moisture content obtained for Lots 1, 2 and 3 were $21.63 \%$, $20.75 \%$ and $26.60 \%$, respectively (Table 3 ).

The high moisture content observed in the lots of pink pepper seeds studied it may have occurred due to its inadequate drying, in the post-harvest phase. However, for future harvests, the seeds will be dehydrated in a greenhouse at $45^{\circ} \mathrm{C}$, until the moisture content of $12 \%$ is reached, allowing the maintenance of their quality for a longer period.

Table 2. Percentage of purity of pink pepper seeds (Lots 1, 2 and 3).

\begin{tabular}{ccccccc}
\hline Lot & $\begin{array}{c}\text { Initial weight } \\
\text { (g) }\end{array}$ & $\begin{array}{c}\text { Pure seeds } \\
\text { (g) }\end{array}$ & $\begin{array}{c}\text { Other seeds } \\
\text { (g) }\end{array}$ & $\begin{array}{c}\text { Inert material } \\
\text { (g) }\end{array}$ & $\begin{array}{c}\text { Impurities } \\
(\mathbf{\%})\end{array}$ & $\begin{array}{c}\text { Purity } \\
\text { (\%) }\end{array}$ \\
\hline $\mathbf{1}$ & 128.1 & 123.5 & 0.0 & 4.5 & 5.8 & 94.2 \\
$\mathbf{2}$ & 113.0 & 110.7 & 0.0 & 2.4 & 2.7 & 97.3 \\
$\mathbf{3}$ & 115.4 & 114.4 & 0.0 & 0.0 & 1 & 99.9 \\
\hline
\end{tabular}

Table 3. Moisture content of pink pepper seeds (Lots 1, 2 and 3).

\begin{tabular}{|c|c|c|c|c|c|c|c|}
\hline Crucible & Lot & $\begin{array}{l}\text { Tare } \\
\text { (g) }\end{array}$ & $\begin{array}{l}\mathrm{Pu} \\
\text { (g) }\end{array}$ & $\begin{array}{l}\text { Ps } \\
\text { (g) }\end{array}$ & $\begin{array}{c}\text { U } \\
(\%)\end{array}$ & $\begin{array}{c}\text { Mean moisture } \\
\text { content } \\
(\%)\end{array}$ & $\begin{array}{l}\text { Total means } \\
\text { moisture content } \\
(\%) / \mathrm{CV}^{*}\end{array}$ \\
\hline 19 & 1 & 27.04 & 32.46 & 31.27 & 21.92 & \multirow{2}{*}{$21.63 \mathrm{~A}$} & \multirow{6}{*}{$\begin{array}{c}22.99 \\
12.78^{*}\end{array}$} \\
\hline 25 & 1 & 25.96 & 31.02 & 29.94 & 21.33 & & \\
\hline 6 & 2 & 28.55 & 33.75 & 32.74 & 19.47 & \multirow{2}{*}{$20.75 \mathrm{~A}$} & \\
\hline 40 & 2 & 36.80 & 41.97 & 40.83 & 22.04 & & \\
\hline 44 & 3 & 43.7 & 49.30 & 47.8 & 26.8 & \multirow{2}{*}{$26.60 \mathrm{~B}$} & \\
\hline 16 & 3 & 39.9 & 45.20 & 43.8 & 26.4 & & \\
\hline
\end{tabular}

$\mathrm{Pu}$ (Wet weight) Ps (Dry weight) U (Moisture percentage) and CV* (Coefficient of variation). Averages followed by the same letter do not differ statistically from each other by the Tukey test at $5 \%$ significance. 
Neves et al. (2016) considers that pink pepper seeds can be stored at $12.6 \%$ humidity for up to five months in the environment without affecting their quality as long as they are packed in a paper bag. However, pink pepper seeds have an orthodox behavior; they resist drying to low values, around 5 to $7 \%$, and can be stored with a low moisture and temperature content, maintaining their viability for a longer period.

Uniformity test (sieve retention). The result shows that $5.66,4.75$ and $4.00 \mathrm{~mm}$ mesh sieve retained 1.67, 49.69 and $37.80 \%$ of the pink pepper seeds, respectively (Figure 1).

Although there is less retention in the sieve with a mesh of $5.66 \mathrm{~mm}(1.67 \%)$ and $4.0 \mathrm{~mm}(37.80 \%)$, the differences were significant and may assist in decision-making about product marketing. On the other hand, larger and more uniform seeds may be sold in natura at a higher price. Instead of being sold at a lower price, the smaller seeds may be used to produce essential oils, adding value to the product.

\section{Sieve Retention}

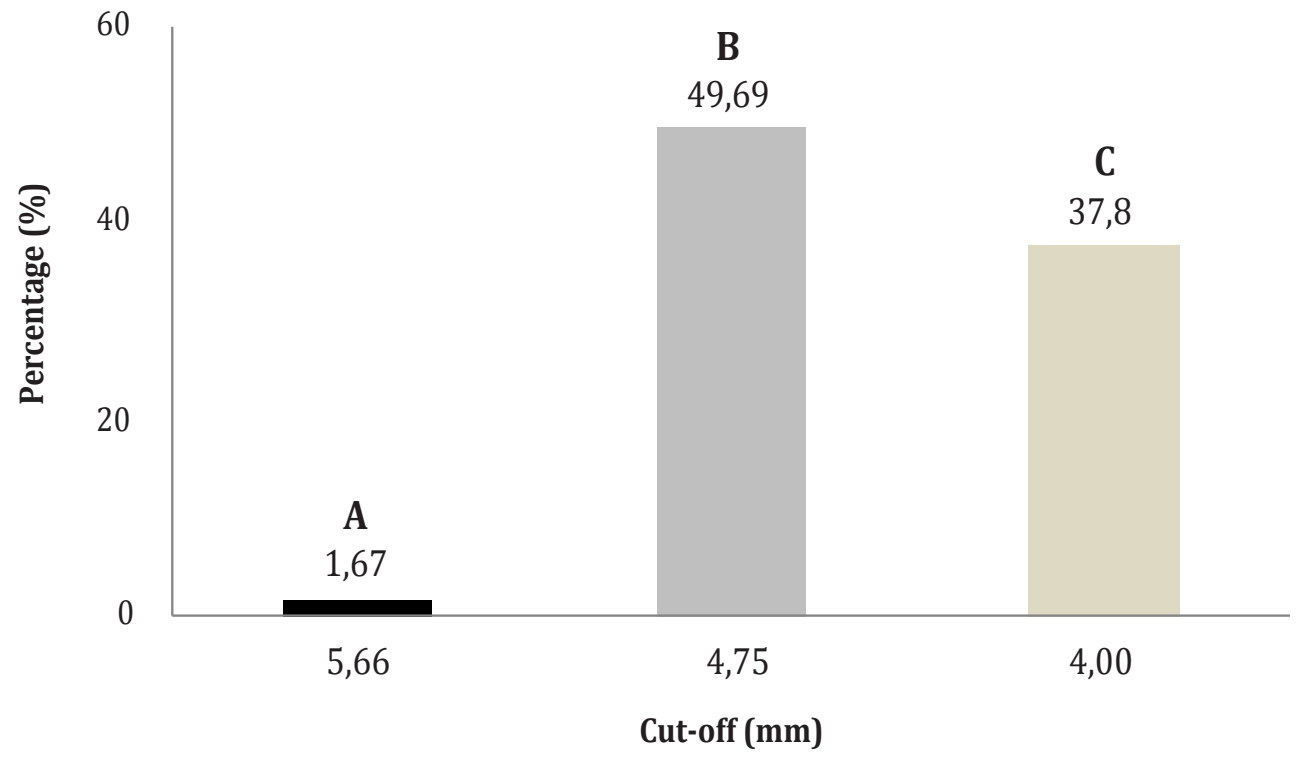

Figure 1. Percentage of seeds retained in a sieve of different meshes (mm). Averages followed by the same letter do not differ at $5 \%$ significance using the Tukey test.

No statistical differences were observed between lots for retention in 3.5 tyler sieves $(5.66 \mathrm{~mm})$. It is observed that the values found for Lots 1,2 and 3 are similar (Figure 2).

For the 4 Tyler sieve $(4.75 \mathrm{~mm})$, it is observed that there were differences between lots, with greater retention of seeds from Lot 1 when compared to Lots 2 and 3. The results obtained indicate Lot 1 presents more uniform seeds, bigger dimensions and better appearance, achieving a better quality standard; than Lots 2 and 3 (Figure 3). 


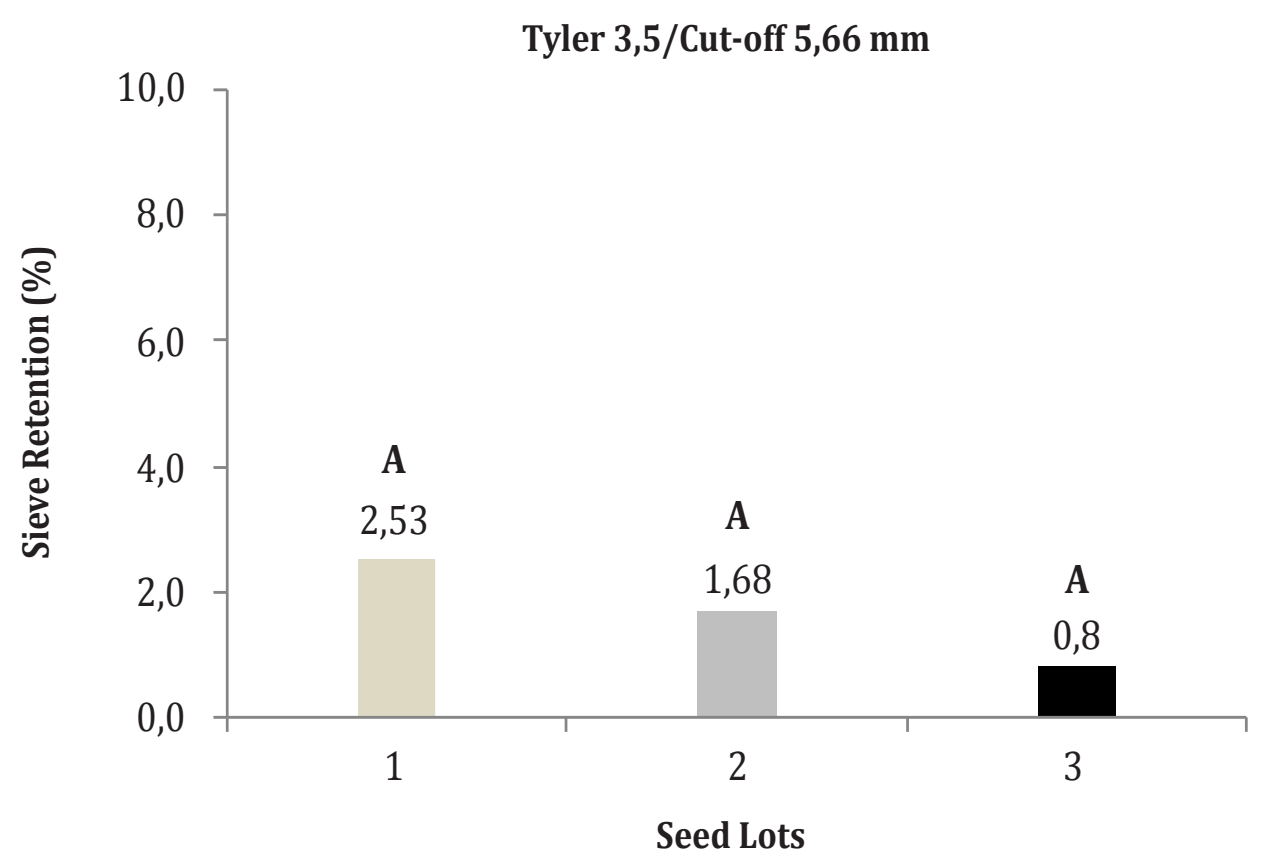

Figure 2. Percentage of seeds retained between lots, for 3.5 Tyler sieve, $5.66 \mathrm{~mm}$ mesh. Averages followed by the same letter do not differ at $5 \%$ significance using the Tukey test.

\section{Tyler 4/Cut-off 4,75 mm}

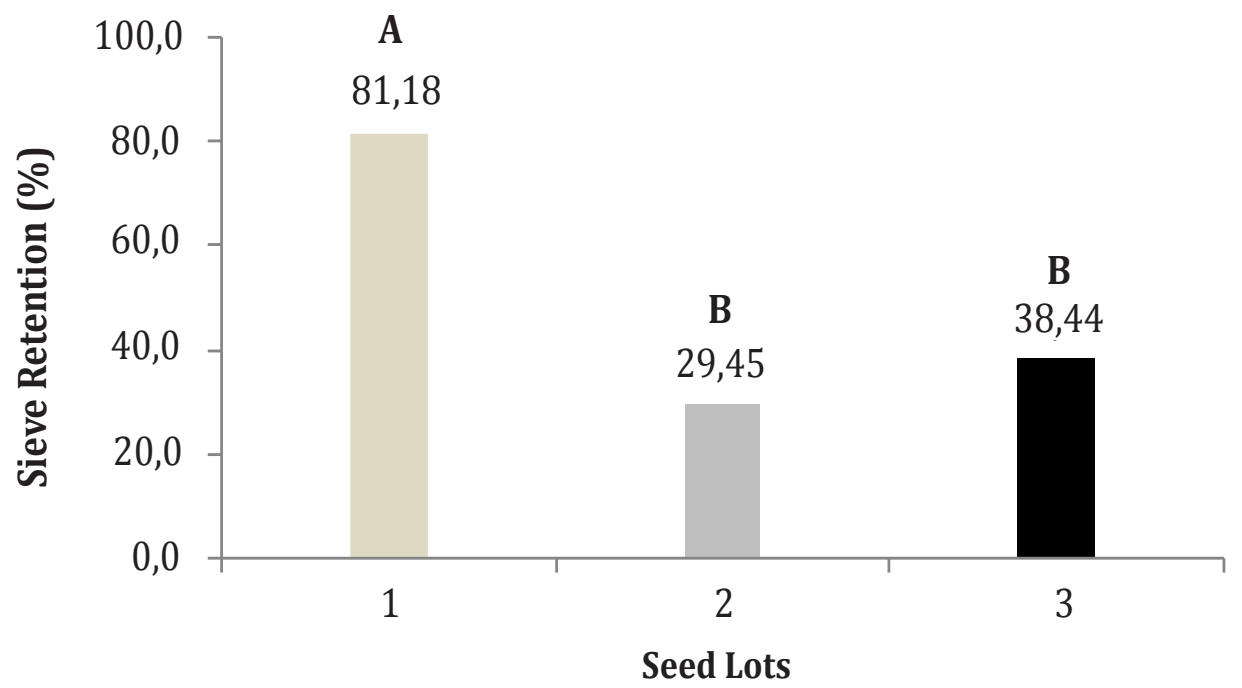

Figure 3. Percentage of seeds retained between lots, for 4 Tyler sieve, $4.75 \mathrm{~mm}$ mesh. Averages followed by the same letter do not differ at $5 \%$ significance using the Tukey test. 
As for the 5 Tyler sieve $(4.00 \mathrm{~mm})$, there was greater retention of seeds from Lots 2 and 3, indicating that these lots are smaller and can be classified for commercialization in a lower quality standard than Lot 1, (Figure 4).
Thousand seed weight. It is observed that there are significant differences at the level of $5 \%$ of significance between the lots for the average weight of a thousand seeds (Table 4).

\section{Tyler5/Cut-off 4 mm}

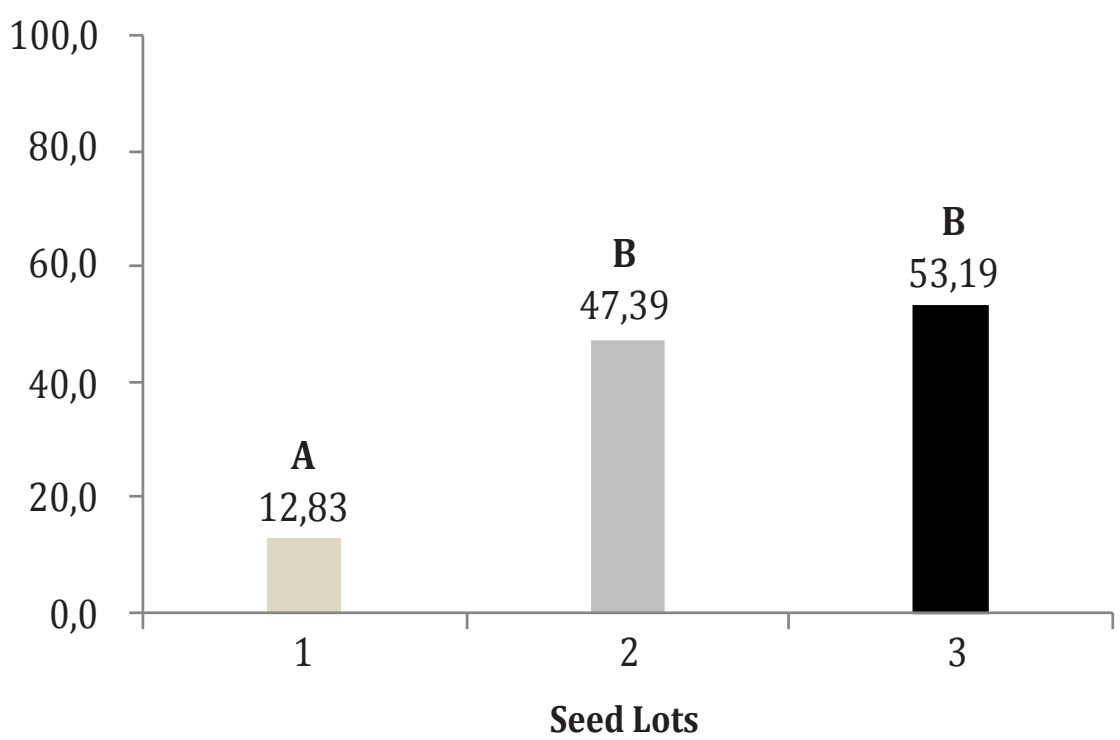

Figure 4. Percentage of seeds retained between lots, for 5 Tyler sieve, $4.0 \mathrm{~mm}$ mesh. Averages followed by the same letter do not differ at $5 \%$ significance using the Tukey test.

Table 4. Results of thousand seed weight tests (Lots 1, 2 and 3).

\begin{tabular}{cccc}
\hline \multirow{2}{*}{ Repetition } & Lot 1 & Lot 2 & Lot 3 \\
\cline { 2 - 4 } & Net weight (g) & Net weight (g) & Net weight (g) \\
\hline 1 & 2.68 & 2.23 & 2.32 \\
2 & 2.66 & 2.17 & 2.29 \\
3 & 2.72 & 2.34 & 2.15 \\
4 & 2.62 & 2.05 & 2.30 \\
5 & 2.20 & 2.01 & 2.32 \\
6 & 2.38 & 2.11 & 2.29 \\
7 & 2.51 & 2.16 & 2.30 \\
8 & 2.45 & 2.13 & 2.30 \\
\hline Seed average & $\mathbf{2 . 5 3}$ & $\mathbf{2 . 1 5}$ & $\mathbf{2 . 2 8}$ \\
\hline Thousand seed weight & $\mathbf{2 5 . 2 7 ~ A}$ & $\mathbf{2 1 . 5 1 ~ B}$ & $\mathbf{2 2 . 8 3 ~ B}$ \\
\hline
\end{tabular}

Averages followed by the same letter do not differ at $5 \%$ significance using the Tukey test. 
This analysis indicates that Lot s 1 seed are larger and have better physical quality than Lots 2 and 3 . This difference may be related to the seeds' maturity, health, and water content (MAPA, 2009), or the endosperm's size, and consequently the number of reserves in the seeds (Ponce et al., 2019).

Germination and vigor test. It is observed that the average germination index is similar between the seeds retained in the $4.75 \mathrm{~mm}$ and $4.0 \mathrm{~mm}$ mesh sieve (Table 5).

The performance of seedlings in the first germination count allows determining the seed's lot quality as performed in this study, by comparing and identifying seeds with a greater or lesser probability of establishing themselves in the field (Guedes et al., 2015). Thus, the results obtained in this study indicate that the seeds present, on average, a high total germinative index $(G=72 \%)$. However, in the first seven days, this value was low, around 20\%, which can be an obstacle in establishing seedlings in the field.

Sustainability assessment. The purity indicator reached an average of grade 3 - highly sustainable; the indicators insect incidence, uniformity in sieve, germination, and vigor reached grade 2 - medium sustainability; and the moisture content indicator reached grade 1 - not very sustainable, (Figure 5).

Table 5. The first, second, and third seedling count, in days, and total germination index $(G)$ of pink pepper seeds retained in the 4.75 and $4.0 \mathrm{~mm}$ sieves.

\begin{tabular}{|c|c|c|c|c|c|}
\hline \multirow{2}{*}{ Tyler/Mesh } & \multirow{2}{*}{ Repetition } & \multicolumn{4}{|c|}{ Number of normal seedlings } \\
\hline & & 7 Days & 14 Days & 21 Days & $\mathrm{G}(\%)$ \\
\hline \multirow{5}{*}{$4 / 4.75 \mathrm{~mm}$} & 1 & 19 & 48 & 2 & 69 \\
\hline & 2 & 19 & 45 & 1 & 65 \\
\hline & 3 & 25 & 49 & 2 & 76 \\
\hline & 4 & 24 & 41 & 1 & 66 \\
\hline & Average & 22 & 46 & 2 & $69 \mathrm{~A}$ \\
\hline \multirow{5}{*}{$5 / 4.0 \mathrm{~mm}$} & 1 & 7 & 68 & 3 & 78 \\
\hline & 2 & 26 & 54 & 1 & 81 \\
\hline & 3 & 22 & 52 & 2 & 76 \\
\hline & 4 & 20 & 42 & 1 & 63 \\
\hline & Average & 19 & 54 & 2 & $75 \mathrm{~A}$ \\
\hline \multicolumn{2}{|c|}{ Total average } & 20 & 50 & 2 & 72 \\
\hline
\end{tabular}

G\% (Total Germination Index). Averages followed by the same letter do not differ at $5 \%$ significance using the $t$ test. 


\section{Sustainability assessment}

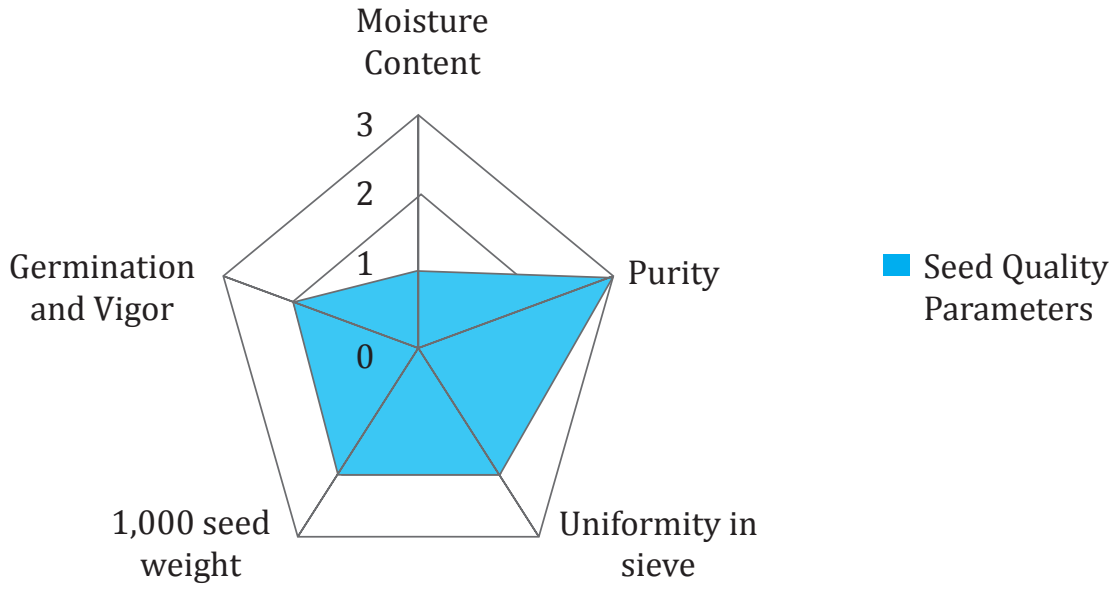

Figure 5. Sustainability assessment chart.

According to the sustainability assessment chart, it can be seen that the purity quality parameter was assigned a grade of 3 . The impurity removal procedure is performed efficiently in the postharvest, contributing to raising the physical and adding value to commercialized seeds.

Only one of the lots presented a satisfactory result in the weight test of a thousand seeds, as indicated by Normative Instruction \#45 of MAPA (2013). Therefore, in the sustainability assessment, this parameter was assigned to grade 2. The results presented point to the need to observe the seeds' health, the moisture content, and the favorable period for the harvest (degree of maturity) since the thousand seed weight may vary to these factors (MAPA, 2009).

Grade 2 was assigned to the uniformity parameter. This parameter varies widely, suggesting that the seeds should be separated by size. Degradation due to humidity and delay in the harvest period are factors to be observed. It may be related to the small size and low uniformity of the seeds. The classification of seeds by size will benefit the commercialization of the product as they can be commercialized by variable size and price.
The high moisture content found in pink pepper seeds is a weak point in the environmental, social, and economic sustainability of the Ademar Moreira settlement's extractivist activity. This characteristic leads to loss of seed quality as it interferes with the increase in the incidence of fungi and deterioration by insects; in addition, it contributes to the reduction of germination and vigor. The moisture content is a parameter that needs to be improved as it can decrease the natural longevity of the seeds. According to Souza et al. (2016), the environmental conditions affect the viability of the seeds; however, the moisture content is one of the factors that most interfere in the conservation of the physiological potential of the seeds. This parameter was assigned to grade 1 .

Regarding germination and vigor, Gomes et al. (2013) highlight that one of the biggest problems associated with the pink pepper stems extraction from the difficulty in maintaining genetically diverse populations to ensure good fruit production for use in both ecological and socioeconomic aspects. For the authors, the adequate storage of seeds contributes to the maintenance of germplasm banks and ensures the rescue of important genotypes for the seedlings 
production for commercial plantations and use in the recovery or restoration of degraded areas. Thus, the high moisture content interferes with germination and causes genetic losses for pink pepper.

Although pink pepper is a product that mostly affects the foreign market, because its production is practically exported to Europe, Asia, and the United States of America (Sodré, 2016). The seeds' collectors are not well paid; because most of the income goes to traders. Thus, the adoption of adequate practices for harvesting, processing and storing of seeds and new processing technologies can add value to the product in natura. For example, essential oilscan guarantee higher income for collectors and increase the sustainability of the pink pepper value chain in the Ademar Moreira settlement.

Conflict of interest: The authors declare that there is no conflict of interest.

\section{CONCLUSIONS}

Among the quality parameters analyzed, the degree of purity was high, but it is necessary to pay attention to the period of fruit maturation, seed size, and moisture content as they affect products' quality.

The best germinative index of the species occurs at 14 days after sowing, and it does not vary between seeds of different sizes. However, the high moisture content of seeds sold by producers (22.99\% on average) interferes with their quality and compromises production. In this way, the Ademar Moreira Settlement is moving towards the sustainability of the pink pepper extraction activity, but it is necessary to incorporate better practices for collecting, processing and storing seeds.

\section{BIBLIOGRAPHIC REFERENCES}

Presidência da República de Brasil. (2006). Lei no 11.428, de 22 de dezembro de 2006. Dispõe sobre a utilização e proteção da vegetação nativa do Bioma Mata Atlântica, e dá outras providências. Retrieved from https://url.gratis/Wz0Zh

Carvalho, N. M.; Nakagawa, J. (2000). Sementes: Ciência, tecnologia e produção. 4ํㅡ. ed. Jaboticabal: FUNEP. 588p.

Gomes, L. J.; Silva-Mann, R.; Mattos, P. P.; Rabbani, A. R. C. (2013). Pensando a biodiversidade: Aroeira (Schinus terebinthifolius Raddi.). São Cristóvão: UFS. 372p.

Guedes, R. S.; Alves, E. U.; Santos-Moura, S. S.; Galindo, E. A. (2015). Teste de comprimento de plântula na avaliação da qualidade fisiológica de sementes de Amburana cearensis (Allemão) A. C. Smith seeds. Semin. Cienc. Agrar. 36 (4): 2373-2382. doi: http:// dx.doi.org/10.5433/1679-0359.2015v36n4p2373

INEA - Instituto Estadual do Meio Ambiente. (2018). Boletim de serviço № 58. Retrieved from https:// cutt.ly/5ktaPM7B

INEA - Instituto Estadual do Meio Ambiente. (2015). Resolução INEA № 124. Dispõe sobre procedimentos e parâmetros técnicos para a exploração florestal sob regime de manejo florestal sustentável. Diário Oficial do Estado do Rio de Janeiro, Rio de Janeiro, № 183, p.15-17. Retrieved from https://cutt. ly/5ktaPM7

MAPA-Ministério Agricultura Pecuária eAbastecimento. (2013). Normative Instruction MAPA 45/2013. Retrieved from https://cutt.ly/zhCV5mG

MAPA - Ministério da Agricultura, Pecuária e Abastecimento. (2009). Regras para análise de sementes. Brasília: MAPA/ACS. 399p.

MAPA - Ministério da Agricultura, Pecuária e Abastecimento. (2013). Instruções para análises de sementes de espécies florestais. Brasília: MAPA. 98p.

Medeiros, A. C. S.; Zanon, A. (1998). Conservação de sementes de aroeira-vermelha (Schinus terebenthifolius Raddi). Boletim de Pesquisa Florestal 36: 11-20. 
Neves, E. J. M.; Santos, A. M.; Gomes, J. B. V.; Ruas, F. G.; Ventura, J. A. (2016). Cultivo da aroeira-vermelha (Schinus terebinthifolius Raddi) para produção de pimenta-rosa. Colombo: Embrapa Florestas. 24p.

Oliveira, F. T. G.; Vitória, R. Z.; Posse, S. C. P.; Arantes, S. D.; Schmildt, O.; Viana, A.; Malikouski, R. G.; Barros, B. L. A. (2018). Qualidade fisiológica de sementes de aroeira em função das condições de armazenamento. Nucleus. 15 (2): 567-574. doi: https://doi.org/10.3738/1982.2278.2959

Ponce, R. M.; Costa, D. S.; Lima,L. H. S.; Ibanhes Neto,H. F.; Takahashi, L. S. A. (2019). Tamanho da semente e potencial fisiológico de trigo sarraceno. Rev. Cient. Rural. 21 (2): 259-268. doi: https://doi. org/10.30945/rcr-v21i2.354

Rossi, R. F.; Cavariani, C.; França-Neto, J. B. (2017). Vigor de sementes, população de plantas e desempenho agronômico de soja. Rev. Cienc. Agrar. 60(3): 215222. doi: http://dx.doi.org/10.4322/rca.2239

Sodré, E. (2016). São Mateus, maior produtor de pimenta-rosa do mundo. Retrieved from https:// cutt.ly/JhCNHf0

Souza, P. P.; Motoike, S. Y.; Carvalho, M.; Kuki, K. N.; Borges-Lima, E. E.; Silva, A. M. (2016). Storage on the vigor and viability of macauba seeds from two provenances of Minas Gerais State. Cienc. Rural. 46 (11): 1932-1937. doi: http://dx.doi. org/10.1590/0103-8478cr20150848

United Nations. (2015). Transforming our world: The 2030 Agenda for Sustainable Development. Retrieved from https://cutt.ly/hkBeg4n 